\title{
Perceptions of Germany unveiled
}

Surveys have revealed the unpopularity of Germany as a place for young foreign scientists. In response, Germans need to improve conditions suffered by academics; foreigners need to think more realistically about the country and its inhabitants.

IT is patronizing but apparently necessary to state that Germany is an exciting and fascinating place for scientists. Visi Max Planck Institute and you will be left in no doubt of the generous scale of funding received by heads of research groups, and the virtually complete autonomy they enjoy in the choice of topics on which to focus. Visit the more favoured laboratories in the east and you will encounter first-class researchers (many imported from the west) building new centres of excellence while grappling with post-reunification problems and opportunities. There are major facilities in plenty, and a fair crop of Nobel prizewinners. Long-term economic prospects are good, so Germany can be expected to go on dominating the league tables of research spending. It is boosting its spending on basic science.

So why do young scientists from other countries not like the place? New figures from the European Commission (EC) show it well down the list of desirable countries in which to spend a year or two doing research. More than 6,000 young scientists applied for fellowships to train in another European Union country under the EC's Human Capital and Mobility (HCM) programme, which ran from 1992 to 1994 . Of these, 1,834 applied to work in Britain, 1,575 in France, but only 556 requested training in Germany. That sad situation persists in the HCM's successor programme Training and Mobility of Researchers (TMR). Barely 10 per cent of approved applications are to work in Germany.

Happily, the perceptions and prejudices that must underlie this abysmal response can be examined and confronted. A recent survey conducted by the German TMR coordinators among fellowship holders working in Germany throws some light on the issues. When asked what had most concerned them about Germany when considering where to train, they cited language, bureaucracy, hostility to foreigners, lack of accommodation and poor images of Germans. Those who took part in the survey, had, by definition, decided to work in Germany despite their misgivings. But the obstacles that others find insuperable need to be dealt with.

The language presents a problem - German is not widely studied in Europe and is undeniably difficult. The German TMR contact office points out that English is the international language of science and every scientist working in a laboratory will be able to speak it. It is true that German scientists are generally happy to practise their English, but long-term visitors wishing to participate in the day-to-day life of the laboratory will have to learn to speak German. The onus is on the visitor, but it is by no means an unrewarding one.

Bureaucracy is a different matter, at least at the universities, where researchers are confronted by extraordinary burdens of regulation. Again, the German contact office is keen to stress that fellows will not be hindered personally. Here there is a wider issue: both research and teaching at German universities are undermined by form-filling distractions, and change can come only with an urgently needed review of university management.

Whether something can be done about Germany's image is another matter. The country is burdened by history and is viewed in many places with suspicion and deep-rooted preju- dice. Stereotypes of the German character are encountered all too often. Furthermore, elements of xenophobia in German society have received considerable publicity. But stereotypes evaporate in the fellowship of professional activity. Furthermore, younger Germans themselves treat history with caution implications are discussed and confronted. And academics took to the streets in their thousands during 1992 to demonstrate against xenophobia: as in Italy and France, Ausländerfeindlichkeit is a serious but regionally contained problem. Such hostility is not likely to confront visitors - witness the hundreds of foreign scientists who work without problems every year in German laboratories, thanks to grants from the Deutscher Akademischer Austauschdienst and the Humboldt Foundation.

The internationalist morals of this tale are twofold. First, where historical burdens and international image are a problem, contacts with visitors can only be helpful. And second, with their own self-interest in mind, young European scientists should look twice at their perceptions, so as not to waste an opportunity to gain from Germany's scientific vigour. But an important goal for the country is to get university life into better shape.

\section{Bad day at Yucca}

The delay in deciding on a site for permanent nuclear waste storage puts feeble politics ahead of decisive management.

HAZEL O'Leary, the US energy secretary, informed a Senate committee last week that permanent storage for spent nuclear fuel cannot begin at Yucca Mountain, Nevada, until 2015 at the earliest - a five-year delay necessitated, she says, by spending cuts. She added that President Bill Clinton would veto a bill proposed by Senator Larry Craig (Republican, Idaho) to establish an interim store at Yucca Mountain to hold the waste until then.

The Senate committee was rightly disconcerted to find that O'Leary has no satisfactory plan for dealing with the spent fuel in the interim. The energy department has a legal obligation after 1998 to take the spent fuel from nuclear power stations, where it is accruing at an alarming rate. But, according to O'Leary, Craig's proposed interim store at Yucca Mountain would upset the local inhabitants, who might then doubt the objectivity of a decision to put a permanent store there.

Add to this talk by Dan Dreyfus, her own nuclear waste manager, of a "very, very high probability" that the permanent facility can be built at Yucca Mountain, and one gains a clear picture of an administration fleeing from politically awkward decisions. Non-technical factors are at work - not least the Clinton administration's reluctance to do anything at all that might offend voters in nearby California.

Senator Bennett Johnston (Democrat, Louisiana) brands the position of his own party's administration on this issue "an outrage of astonishing dimensions". Such bluntness is justified. The nuclear waste issue is fraught with difficulty. It is nonetheless regrettable that the current administration so palpably lacks the courage to confront it. 